(1) 1991 ISI.J

解 説

\section{放射光利用による材料解析}

\title{
Materials Characterization by Synchrotron Radiations
}

Hirofumi Morikawa and Koichi KaWasakI

\section{1.はじめに}

放射光はシンクロトロン放射またはシンクロトロン軌 道放射 (Synchrotron Orbital Radiation) とも呼ばれ, 略して SR または SOR と称される (以下 SR と略記). 彷米の X 線源に比し 1000 傍という超高強度線源であ るばかりでなく, 白色性, 波长選択性, 高壮徃, 偏光 性，パルス性などの優れた特徽を持ち, “莎の光”と呼 ばれている。日本では筑波の高エネルギー物理学研究所 に壮界的にも最高エネルギーレベルの $2.5 \mathrm{GeV}$ を持つ 放射光専用の䒠験施設 (以下 PF と略记) が没菅され 1982 年より本格们に稼働している。また 1990 年末に高 輝度光科学:研究センターが発起し, 数年後には西插磨科 学:公湖都市内に強力な放射光施設, SPring-8 $(8 \mathrm{GeV})$ の稼働が予分されている。

材料のキャラクタリゼーションを行う、で近年発展し た分野のなかで前凹（1974 年）の特集少以降で大きな飛 躍がもたらされた新機器の.つに, ミク口攽域の解析手 段があげられる。たとえば分析電子顕微鏡の简性能化に 伴い析出物や介在:物の间芫が行易となった。また超简分 解能電一顕微鏡, アトムプローブ電界イオン顕微鏡, 走 查トンネル顕微鏡などの资用化と性能们卜がす寸み，い わゆる原子オーダーの材料情報が得られるようになって いる.これらについては, 本特集少でも詳しく述べられ

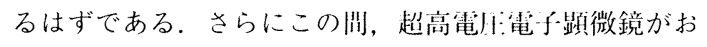
おいに発展し, 動的挙動の観祭, その場観然が材料の才 学的特性や組織变化などに関する基本的な性質の解明に 奇子してきた。

材料の研究開発の観点に立つと, 上述の研究手法は坊 効であったし今後も重要な手段であろうが，いっぽうで

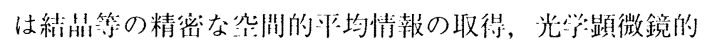
視野での時閏的組織変化のリアルタイム钼祭, 超杨䘚们

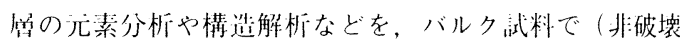
で）あいは䒜网父制御のもとで行えることも构めて重 要である．SR はこれらのニーズにも適个寸る研究開発 手段として期街される.

そこで本解说ではまず SR の特微を概観し，ついで

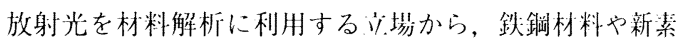
材の材料解析への放射光の忍用例について逨べたい，

なお SRに関しては，WINICK and DoNIAC川 編の解说茟1)

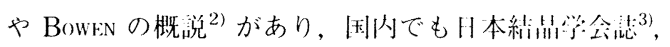

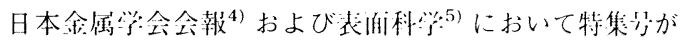
組まれているので参照されたい。

\section{2. 放射光の特徵}

\section{$2 \cdot 1$ 放射光とは}

シンクロトロン放射光とは, シンクロトロン型粒一加 速器によって光速度に㢦めて近い速度に加速された荷電 档子がその進行す问と们父する扠速度を受けるとき(た とえば磁場を横切るとき）に放射する毛磁波である．放

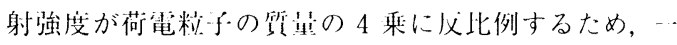

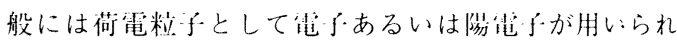
る。すなわち、似1のように光速近くまで川速された 電子(または隄電子) が，磁イてでその轨通が曲げられる

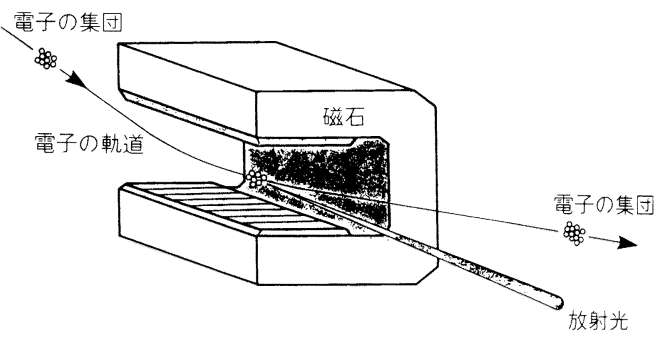

沙 1 放射光の発牛:

壮成 3 年 3 月 25 日受付 (Received Mar. 25, 1991) (低頼解跘)

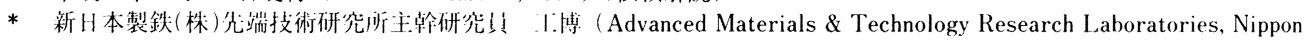
Steel Corp., 20-1 Shintomi Futtsu 299-12)

*2 新H本製鉄(株)光端技術研究浙主任研究是（Advanced Materials \& Technology Research Laboratories, Nippon Steel Corp.)

Key words : synchrotron radiation ; materials characterization ; X-ray topography ; EXAFS ; XANES ; abnormal absorption; structure analysis; surface analysis. 


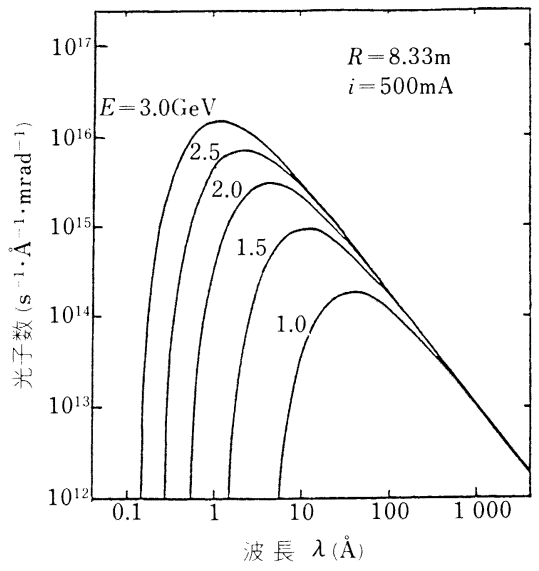

汹 2 放射光のスペクトル

際に放射される輝度の紐束の電磁波であって，電子

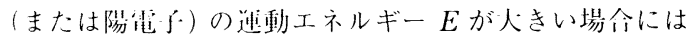

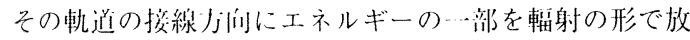
出する制動輜射である。一般に輻射は笔波領域から硬 X 線領域にまたがる速続スペクトルとなるが，電子の エネルギーをパラメーターとしたスペクトル缚度と光波

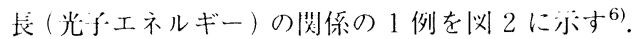

\section{$2 \cdot 2$ 放射光の特徴}

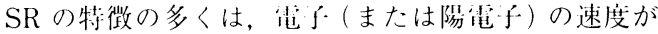
光速度に近いことに起体する。

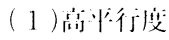

・般的な X 線管球では宨子がターゲットに执いて減 速することによる俳動放射が件じて主色X 線となり， 全方位に放射される。SRでは粒与の制動放射は速度

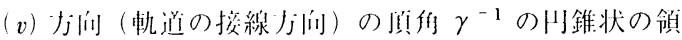
域だけに钼测され，指问性が流い。ここで $\beta=v / c$ と すると， $\gamma=\left(1-\beta^{2}\right)^{-1 / 2}$ であり, $\mathrm{PF} て ゙ は 2 \gamma^{-1}$ は 1 $\min$ 程度である。

(2) 袖耀度:

仮にX 線管球の㪀射を SR と间様に $\gamma^{-1}$ の川錐に集

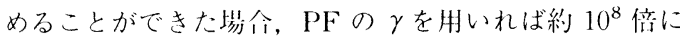

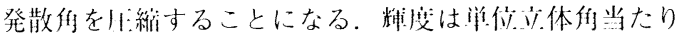
の弶度をさすので，粗度は $10^{8}$ 作となるべきであるが，

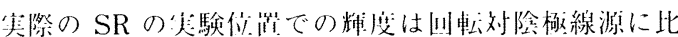
べ，色色で $10^{3} \sim 10^{4}$ 倍，特性Ｘ線に刘しては $10^{2}$

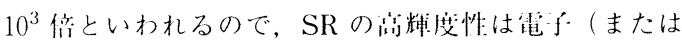

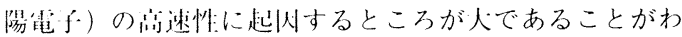
かる.

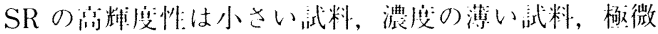

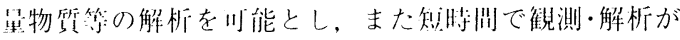
行える。

(3) 向色州:
電子（または陽電子）の連動にともない，細い円錐が 円軌道面上で光速に近い速度で振り回されるので，軌道 面上の一点で観測される放射は非常に時間幅の狭いもの となる，放射のスペクトルは強度の時間変動をフーリエ 変換したものであるから，四 2 のように SR は叮視〜 紫外〜X 線域の光を含む滑らかな連続スペクトルとな る.

$\mathrm{SR}$ が白色光であるということは, 白色光としての利 用の他に，モノクロメーターによって波長を選択するこ とにより，単色光としての利用も叮能となるということ である．所望の単色光を用いて EXAFS や異常散乱実 験が行える (後述).

\section{(4)偏光性}

$\mathrm{SR}$ の偏光の様子は観祭者の軌道面からの見込み角 $\Psi$ と, 観祭する光の波長入によって異なる。足性的には, 軌道面上 $(\Psi=0)$ では軌道面に電気べクトルが平行な 完全な㨁線偏光で，角度を持つ $(|\Psi|>0)$ にしたがい 棈円偏光となり，垂㨁 $(\Psi= \pm \pi / 2)$ に近くなるほど円 偏光に近づく.PFではほとんどの取り出しラインで $\Psi=0$ であり，完全な偏光と考えてよい.

積極的に偏光性を利用する実験としては，X 線磁気 散乱や偏光 EXAFS などがある.

(5)パルス性

シンクロトロン型の加速器では高㰣波電源を用いて粒 子を加速する。電源部の電場の波にたいして一定の範囲 の位相関係を持つ電子(または陽電子) のみがエネル ギーを受け，それ以外はエネルギー的にはロスになる。 したがって定常的にのこる電子(または陽電子) は一定 の閒隔に並んだいくつかの塊（バンチ）に分かれて軌道 上をまわる。

これの利用によって過渡現象や必忠中闒状態の研究が 期待される.

さらに SR は光源からフォトンのみ放出するクリー ンな光であり，ノイズの少ない高精度の測走が川能であ る.

これまで，通常の偏问磁石による SRに限って述べ たが，SRにはこの他に挿入光源による放射がある.こ れについての説明は参考書に譲る ${ }^{1) ５ ． ~}$

\section{3. 放射光による材料解析}

放射光による材料解析は現在:半導体材料，無機材料が 主体となっており鉄鋼材料など金属材料の分野ではまだ スポット的利用にとどまり本格的活用がなされていな い. 金属材料のうちでは機能材料の力が構造材料より多 く放射光利用の対象とされている. 金属材料研究への忍 用については川崎・前田らの解説も参照7) されたい.

\section{$3 \cdot 1$ 材料の動的解析}

$3 \cdot 1 \cdot 1$ 動的解析の意義

製造门程，使用状態における材料の動的構造変化の把 
握, 高速現象の解明, 動的物性の測定などを目的として 動的解析が行われている。このような動的解析に関して は従来適切な解析手段がなく、ブラックボックスとして 末解明のまま残されていることが多い，放射光に上る動 的観祭は非破壊であり試料のバルク性を損なわずに素過 程に近ることができる．以下に放射光白他 X 線卜ポグ ラフ法と高速計数検出器法の代表的研究例について述へ る.

\section{$3 \cdot 1 \cdot 2$ 動的解析研究の現沉}

(1)放射光白色 X 線卜ポグラフ法

放射光白色 X 線トポグラフ法を利用した研究が数例 報告されている.

鉄鋼材料に関しう䢹性電磁鋼板の二次再結昆過程, $\mathrm{Fe}-\mathrm{Si}$ の粒成言, けい素鉄の凝固過程が研究されてい る. 方问性電磁鋼板の二次再結出過程の動的観祭では高 分解能 X 線テレビを使用した高速现象観祭8)が行われて 扔り本特集に揭載されている。䊉成垃速度の温度依佰性 の研究9) は文献 8）の研究を発展させたもので以下に紹 介する， $\mathrm{Fe}-\mathrm{Si}$ の粒成長 ${ }^{10)}$ は X 線フィルムを使用した 緩漫な現象観祭で, 文献 8) に概貺してある。けい素鉄 の凝周過程の研究 ${ }^{11}$ も以下に紹介寸る.

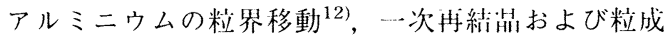
長 ${ }^{13)}$ も動的に観祭されているが X 線フィルム（あるい は微粒子乾板）に低分解能 X 線テレビを併用した緩漫 な現像観祭でやはり文献 8) に概説してある。

$\mathrm{Si}^{14)}, \mathrm{GaAs}, \mathrm{InAs}$ など ${ }^{15)}$ の半浮体の融解, 凝周過 程の動们観祭も精力的に行われている.

・二次再結昆粒成长過程の動的観察

動的解析を目的とした实験設備が高エネルギー物理学: 研究所放射光実験施設に備えられているが, 中でも高速 $\mathrm{X}$ 線卜ポグラフイ装崷 ${ }^{16)}$, 谓接型 $\mathrm{X}$ 線 TV カメラ ${ }^{17)}$, 間接型 X 線 TV カメラ ${ }^{18)}$ が動的像観祭の基本的装萱で あり大きな武器となっている。

これらの測定器に高性能加熱灯を組み命わせた〈放射 光動的頻微トポグラフ法〉により電磁銅板の二次抙結品 粒成长過程での不均一かつ不連続な二次将絬出界面移動 挙動が明らかにされている8). 间手法を用い二次舟結出 粒力位による粒成走速度の温度依你性の相違について研

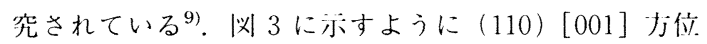
(ゴスオ位とも呼ばれる。（110）は板泊に平行な綃昆格

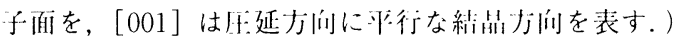
の結昆粒は綃品方位がゴス方位から離れた結昆よりも成 長速度が大きい。 しかもその速度差は $1000^{\circ} \mathrm{C}$ 付近で 人きくなることを見いだした．汹 3 の縦軸の成垓速度 は最大值で示したがこれは不連続な移動挙動での代表值 としての意味を有する (文献 8）参照).

さらに開接型 X 線 TVカメラを用いた〈放射光動的 ラウエトポグラフ法〉による二次将絬昆核生成過程の動 的観察も行われている ${ }^{19)}$.

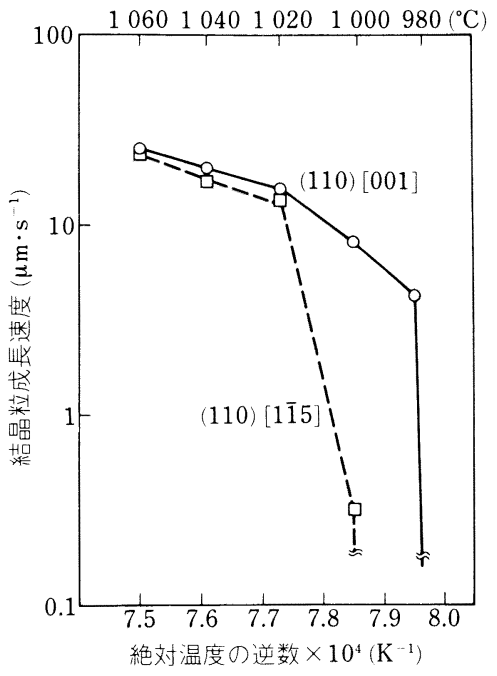

汹 3 電磁鋼极の粒成垃速度の滥度依保性

- 融解, 凝固過程

けい素鉄の凝固時の冏液界洦の動的観祭によりセル状 凝固から平清凝周への遷移条作の從来モデルとの一致が 確認されている ${ }^{11}$ 。ままたセル状凝阔での七ルの䦌隔は 凝婟速度の增大とともに小さくなっていることも確認さ れた。

( 2 ) 高速計数検出器法

高速計数検出器法ではシリコンウエハのレーザーア ニーリングの極短時䦌現象解析が注目される。

パルスレーザーをシリコンウエハ表泊に照射した淔後 の極短時閏の現象解析が皂速検出系を用いて行われてい る. 米国コーネル大峃の放射光施設 (CHESS) では放 射光の発光阏期を十分垃くして (2560 ns)，その成期内

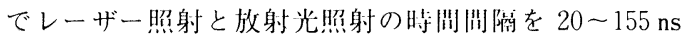
に変化させて測定する手法が研究されている ${ }^{20)}$. 時閒 䦌俩を一定にし結品の解度を変化させて測定された X 線回折ピークの非対称性から深さう问の埧度分布が計算 されている，日本の PFでは放射光は発光凬期が短い ままで連繶発光とみなし X 線検忚器の電気信男をレー ザー照射後一定時䦌後に取り出す手法によりX 線回折 ピークが精密に測这されている21)。また MCS (Multichannel Scaling)による1湖のピーク強度の時间変化も 近跡されているが, $200 \mathrm{~ns}$ ごとの時润変化が解析以能

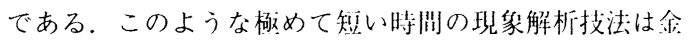
属系材料にも心用川能と考えられる。

米国スタンフォード人学:の放射光施设（SSRL）に求 いてエネルギー分散方式の検出器による動的解析が試み られている.X線回折スペクトルは数秒ごとに単一ピー クは数 $\mathrm{ms}$ ごとに動的測分が川能である、QAIRIらは非 品翼 $\mathrm{Fe}_{83} \mathrm{~B}_{17}$ の綃昆化過程を解析している ${ }^{22)}$. 


\section{$3 \cdot 2$ 材料の構造解析}

EXAFS，XANESによる原子のの兄泣構造解析の总用 搪大とともに衣泊, 動们を命め微怕化, 过速化が研究さ れている。 EXAFSは吸收端付近のX 線の收收率の変

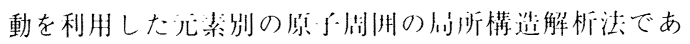
る. XANES は以仪端そのものの微紼構造である。また

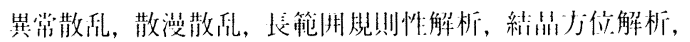

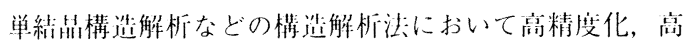

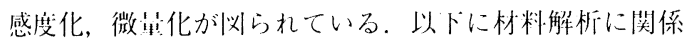
した研究例を紹介する。

\section{$3 \cdot 2 \cdot 1$ EXAFS $\cdot$ XANES}

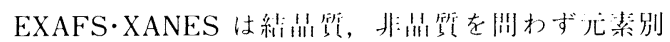

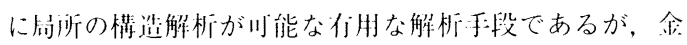
属への忠朋はさほど多くない。令後の利用搪人が㖨まれ る.

洞4に活エネルギー物理受研究所で測足された

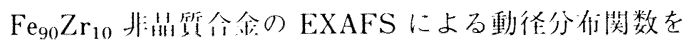
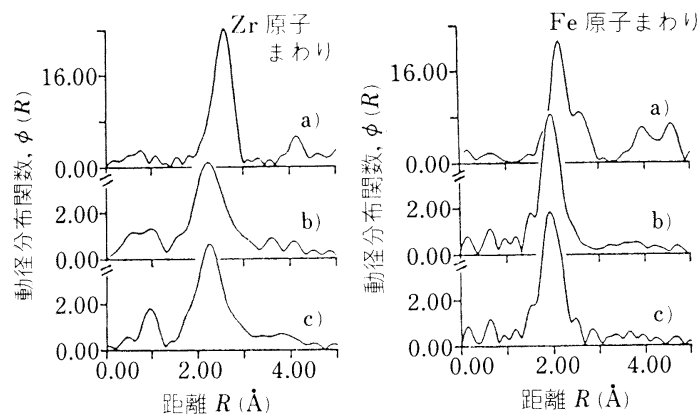

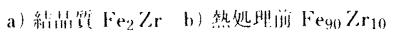
c) 䓡処䧉淩 $\mathrm{Fe}_{90} / \mathrm{r}_{10}$

洞 $4 \quad \mathrm{Fe}_{90} \mathrm{Zr}_{10}$ 非早管介食の EXAFSによる動栙 分们関数

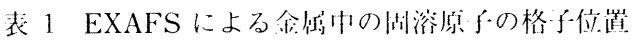
と格子ひずみの測定

\begin{tabular}{|c|c|c|c|}
\hline 洲撂原了。 & 溶媒㷧。 & 位 隹 & $d-d_{\text {idcal }}(\AA)$ \\
\hline $\mathrm{Mg}$ & $\Lambda \mathrm{l}$ & S & 0.076 \\
\hline$\% n$ & $\mathrm{Al}$ & $S$ & -0.02 \\
\hline Sn & $\mathrm{Cu}$ & $\mathrm{S}$ & 0.08 \\
\hline $\mathrm{Ti}$ & $\mathrm{Ni}$ & $\mathrm{S}$ & -0.015 \\
\hline $\mathrm{Cu}$ & $\mathrm{Ti}$ & $\mathrm{s}$ & $-0.05 \pm 0.045$ \\
\hline $\mathrm{Cu}$ & $\mathrm{Ca}$ & I & $0.02 \pm 0.03$ \\
\hline $\mathrm{Cu}$ & Sc & I & $\begin{array}{r}0.43 \\
-0.53\end{array}$ \\
\hline $\mathrm{Cu}$ & $\mathrm{Al}$ & $\stackrel{S}{S}$ & $\begin{array}{l}-0.0,3 \\
-0.125\end{array}$ \\
\hline Gid & l'd & $S$ & $0.052 \pm 0.004$ \\
\hline $\mathrm{Nb}$ & $\mathrm{Ni}$ & $\mathrm{S}$ & 0.06 \\
\hline$Z \mathrm{r}$ & $\mathrm{Ni}$ & $\mathrm{AE}$ & \\
\hline Y & $\mathrm{Ni}$ & $\Lambda \mathrm{E}$ & \\
\hline $\mathrm{Ni}$ & Ti & $A \mathrm{~F}$ & \\
\hline $\mathrm{Ni}$ & $\mathrm{Nb}$ & $\mathrm{AE}$ & \\
\hline V & $\mathrm{Ni}$ & $\mathrm{S}$ & $-0.03 \pm 0.03$ \\
\hline $\mathrm{Ni}$ & V & $S$ & $-0.02 \pm 0.02$ \\
\hline $\mathrm{Cu}$ & V & $\mathrm{S}$ & $0 \pm 0.03$ \\
\hline $\mathrm{Fe}$ & $\mathrm{Cu}$ & $\mathrm{S}$ & 0.01 \\
\hline
\end{tabular}

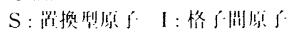

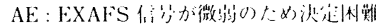

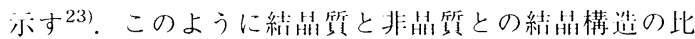
䡈, 熱処理前後の構生変化が解析できる.

圭 1 に米国スタンフォード人学:の放射光施設(SSRL) と米国コーネル大学:の放射光施没 (CHESS) において 测资された蛍光 EXAFSによる金属中の同溶原子の格 子仿莦と格子ひずみの測定例を示す ${ }^{24)}$. 北料は急彾法 により製作された。湖浴金咸の濃度は 0.5 1 at \%であ る. 崷換型原子と格子䦌原子の区别が示されている.

XANESにより超伝浮酸化物の酸素原子の圭範同規剘 度が超伝尊特性の主要な支配因子であることが研究され ている ${ }^{25)}$. 洞 5 に示すように $\mathrm{Cu}$ 吸収端の XANESを 標準試料の XANES と比較することにより武料の原子 価が推定できるとしている。実線は $\mathrm{Y}-\mathrm{Ba}-\mathrm{Cu}-\mathrm{O}$ 系超 伀酱酸化物で破線は標準試料である，P1の光子エネル ギー範网のピークに注目すると $\mathrm{Y}-\mathrm{Ba}^{-} \mathrm{Cu}-\mathrm{O}$ 系超伀浮

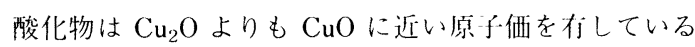
と推定される。また熱処理により酸素量を増加させると P2でのピークの低下が生じるとの知見も得ている.

動的 EXAFS·XANESによる手法開発は最先湍の研 究である。透過法による動的 EXAFS・XANES 法が分 散型X 線吸收スペクトロメーターにより策现してい $ろ^{26)}$.このお法はローランド円に沿って湾曲させた $\mathrm{Si}$

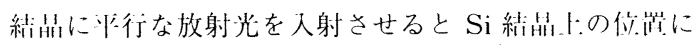
よりブラッグ角が变化し波挂が連続的に变化した惮色光 が収束ビームとして得られる現象を利用している。収束 ビームの焦㔯に試料を峉き試料を透過した発散ビームを …次元検出器で測定する。検出系の単位检少時䦌は最小 $10 \mathrm{~ms}$ である. 硝酸第一鉄とチオ硫酸ナトリウムの浴液 を高速液混令装㯰により混令し鉄の K 吸収端の動的 XANES を測起しているが，1 $\mathrm{s} こ ゙ と に$ 明暸な变化を検 肘ている。

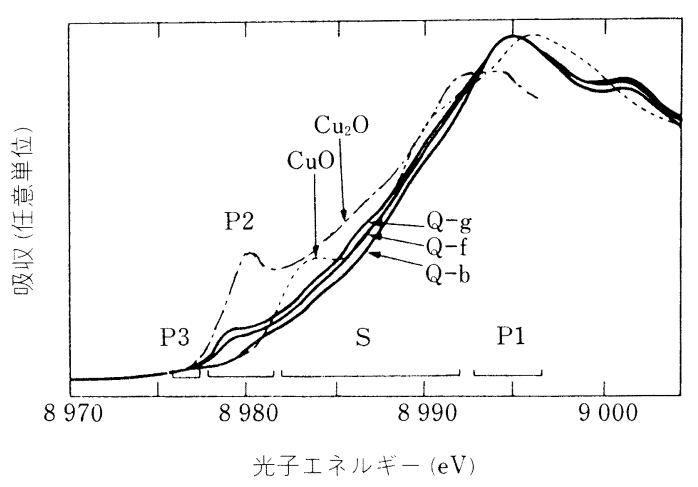

$\mathrm{J}$ 線 : $\mathrm{Y}-\mathrm{Ba}-\mathrm{Cu}-\mathrm{O}$ 系超伀尊酸化物 (Q-gなどは试料の熱処理の迨いを小寺

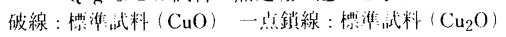

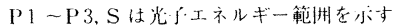

汹 5 超伝敫酸化物の $\mathrm{CuK}$ 吸収端における XANES 


\section{$3 \cdot 2 \cdot 2$ 罳密散乱}

異常散乱法は放射光の波长川変性という特徽を活湖で きる手法で元素別の構监情派を知りうるので今後の利用 が搪大していくと考えられる。ハフニウム/鉄多穈薄膜 の酸化性需囲父中烧鈍、武料について罳常散㵇法により $\mathrm{X}$ 線回折ピークがハフニウム系であるか鉄系であるか が分離・间定されている27).

\section{$3 \cdot 2 \cdot 3$ 単絬早構造解析}

放射光とイメージングプレートを用いた微小結品の信

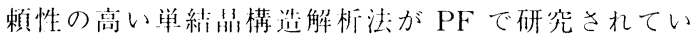
$ろ^{28)}$. 単絬㫨構造解析においては解析のための十分な 人きさと兮金性を们する梁紏早試料が得られにくいこと が解析上の大きな問題である。また試料形状による吸仪 補正と結昆の光企性は解析・の重荄パラメーターであり ながら高精度のデータが得られないため解析の精度を患 化させている。これらの䦓題をクリアーするためには微

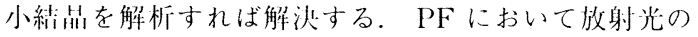
高輝度性とイメージングプレートの高感度性を活用した

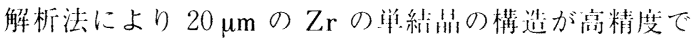
解析されている。

\section{$3 \cdot 3$ 材料の表面分析}

極微量分析, 高感度分析などの新手法が開発されつつ ある. in-situX 線比折, 動们表泊 EXAFS などの動的 表消分析も発展するであろう。

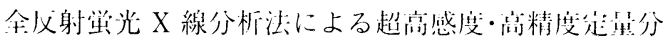

析29)については本特集少を参县されたい。

アンジュレーター光によるオージェ览子分光の感度们

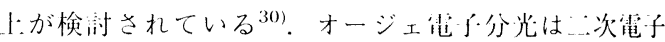
の影響を受け検忺下限が $0.5 \%$ と品い。放射光のアン ジュレーター光はエネルギー分们に陑を持つが，䗆度が

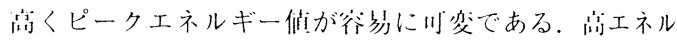
ギー物理学研究䜣の放射光験施没のアンジュレーター 光を用いてチタンの探索的分析を行い, 电子線䚮起デー

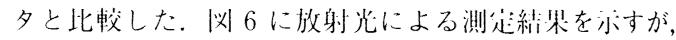
$5 \mathrm{kV}-5 \mu \mathrm{A}$ の電子線泇起と间程度のスペクトルが得られ ている。アンジュレーター光のエネルギーがオージエ電 ケエネルギーよりわずかに人きいときに、才ージェ䉓子 敞度が最大となることから，アンジュレーター光のエネ ルギーの選扒により槀感度化が期待できる。また微小領 域分析も川能と考えられる。

表目の膜成垃をin-situで解析する手泣の检测が行わ れている，英国の放射光施没（Daresbury）に挃いては

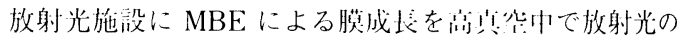
低的度人射表而 X 線叫折㧍よびオージェ, RHEEDに

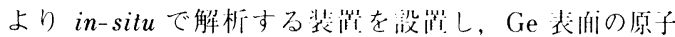
レベルでの構造を解析しているが，X線四折によるロッ キングカーブにより表旧状恁が们效に解析されてい $\gtrsim^{311}$.

PFにおいては MBEによる膜成长を高高突中で放射

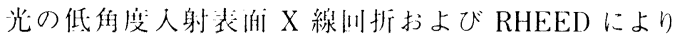

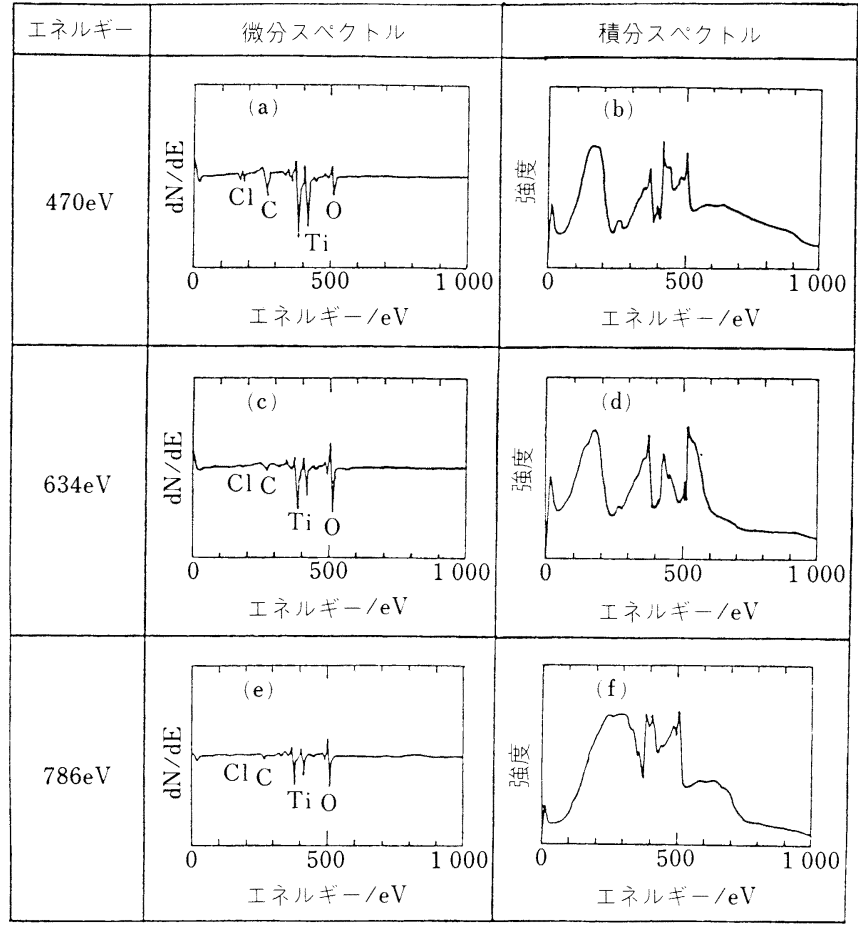

㲸 6 アンジュレーター光により狱起した チタンのオージェ舶子分光スペクトル 
in-situで解析する装喵により， $\mathrm{Si}$ 衣洦扩よび $\mathrm{SiO}_{2} / \mathrm{Si}$ 界阳の原了構造が解析されているが，やはりX線山折 により超構造が们效に解析されている321.

\section{4.おわりに}

以上放射光利湖による材料解析について概括したが， その住効性がホされつつあり令後の利用がますます位 がっていくものと確信する。ここで放射光利用の将来に ついて人型放射光を会めて考えてみたい.

高エネルギーの人型放射光の開発により忍用範网の拡 大が想される。高輝度化により以下に述べるような量 的な変化と留的な変化がもたらされよう。

量的な変化としてはより简速の, より知时間現哀の解 析，より厳しい環境下での解析，像解析技術の位㯰分解 能の问上，演感度化によるより微星武料の解析・分析沶

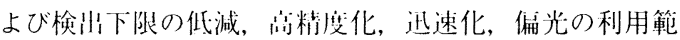
用の搪人などがあげられる。

質的な変化としては知波柱化すなわち X 線透過力の 们、による将い材料の解析が期待される。また高輝淮 $\mathrm{X}$ 線ミクロプローブの尖朋化による后沂解析が望まれ 万.

将来放射光利用が米淙休材料，無機材料主体から全属 材料を含めた冬程材料へと多様化していくと考えられる が，放射光による材料研究の進起は今後も人いに期待さ れる.

\section{文献}

1) Synchrotron Radiation Research, ed. by H. WINICK and S. Doniach ( 1980) [Plenum]

2) D. K. Bol:N: Microstructural Characterization of Materials by Non-Microscopical Techniques., Denmark (1984) [Riso National Laboratory]

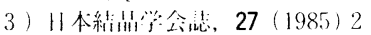

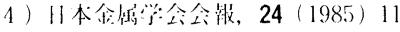

5) 表目科\%, 7 (1986) 1

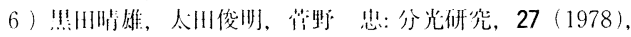
p. 235

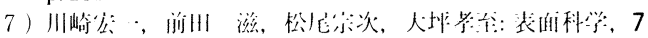
(1986), p. 91

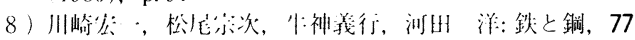
(1991), p. 2044

9 ) Y. Ushiliami, Y. Sura, $N$. Takahasill, $K$. Kawasaki, $Y$.
ChiKalira and H. KII: J. Mater. Eng., 13 (1991), p. 113

10) I. B. MACCoRMaCK and B. K. TANnkR: J. Appl. Cryst., 11 (1978), p. 40

11) T. Matslimiya, $W$. Yamada, T. Ohashi and $O$. NitTono: Metall. Trans. A, 18 (1987), p. 723

12) J. Gastaldi and C. Jouridan: Phil. Mag., A50 (1984), p. 309

13) $W . J$. Boettinger, $H$. E. Buridette and $M$. Kuriyama: Applications of X-Ray Topographic Methods to Materials Science (1984), p. 283 [Plenum]

14）千川純一: シンクロトロン放射（H本物理学:公編） (1986), p. 112 [幥㜄館]

15）佳藤史郎: 放射光, 1 (1988), p. 39

16) S. Suzuki, $M$. Ando, $K$. Hayakawa, $O$. Nittono, $H$. Hashizumb, $S$. Kishino and $K$. KoHra: Nucl. Instr. and Meth. Phys. Res., 227 (1984), p. 584

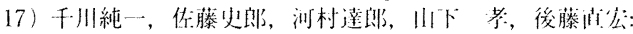
H本結昆学全彭, 24 (1982), p. 295

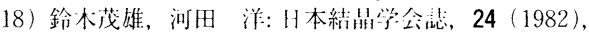
p. 299

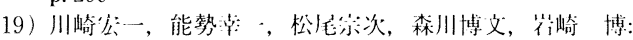
材料とプロセス, 4(1991), p. 407

$20)$ B. C. Larson, $C . W$. Wiite, T. S. Noggi.e, J. F. Barhorst and D. M. Mil.t.: Appl. Phys. Lett., 42 (1983), p. 282

21) $S$. Kawado, $S$. Kojima, $T$. Ishikawa, $T$. Takahashi and $S$. KikUTA: Rev. Sci. Instrum., 60 (1989), p. 2342

$22)$ S. B. QAinki, W. T. El.am, J. D. Ayers, C. L. Vold, E. F. Skelton and $A$. W. Webi: Nucl. Inst. and Meth. Phys. Res., A246 (1986), p. 817

23) $H$. Mafida, $H$. Terauchi, $N$. Kamijo, $M$. Hida and $K$. Osamura: Photon Factory Activity Report, \#2 (1983/1984), p. VI-53

24) M. A. Marcus and C. L. Tsai: Proc. 5 th Int. Conf. on Rapidly Quenched Metals (1985), p. 517

25) $M$. Kimura, $M$. Matsuo, $M$. Murakami, $K$. Sawano and $S$. MATSUda: ISIJ Int., 29 (1989), p. 213

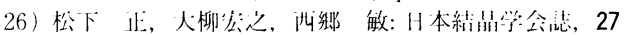
(1985), p. 77

27) M. Imaftiku, $Y$. Takagi and S. Sasaki: Photon Factory Activity Report, \#6 (1988), p. 212

28) $K$. Ohsumi, $K$. Hagily and M. Ohmasa : J. Appl. Cryst., 24 (1991); p. 340

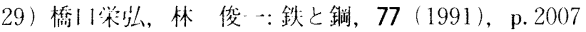

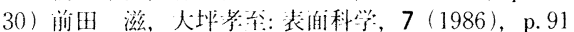

$31)$ E. Vilikg, $A$. Van' t Ent, $A$. P. de Jongih, H. Nerkingis and Van der Vkik: Nucl. Instr. and Meth. Phys. Res., A262 (1987), p. 522

32) K. Акimoto, J. Mizuki, I. Hirosawa and J. Matsui: Rev. Sci. Instrum.. 60 (1989), p. 2362 